\title{
Chronic and asymptomatic diseases influence the control of hypertension treatment in primary care
}

\author{
Cronicidade e doença assintomática influenciam o controle \\ dos hipertensos em tratamento na atenção básica \\ Cronicidad y enfermedad asintomática influencian el control de \\ los hipertensos en tratamiento en la atención básica
}

Angela Maria Geraldo Pierin¹, Stael Silvana Bagno Eleutério da Silva², Flávia Cortez Colósimo², Gabriela de Andrade Toma $^{1}$, Talita de Souza Serafim ${ }^{1}$, Paolo Meneghin ${ }^{1}$

How to cite this article:

Pierin AMG, Silva SSBE, Colósimo FC, Toma GA, Serafim TS, Meneghin P. Chronic and asymptomatic diseases influence the control of hypertension treatment in primary care. Rev Esc Enferm USP. 2016;50(5):763-770. DOI: http://dx.doi.org/10.1590/S0080-623420160000600008

${ }^{1}$ Universidade de São Paulo, Escola de Enfermagem, São Paulo, SP, Brazil.

${ }^{2}$ Universidade de São Paulo, Escola de Enfermagem , Programa de PósGraduação em Enfermagem na Saúde do Adulto, São Paulo, SP, Brazil.

\begin{abstract}
Objective: To identify the association between blood pressure control and the following variables: a) bio-social and lifestyle characteristics of hypertensive patients; and b) factors related to the antihypertensive treatment. Methods: This is an exploratory study with 290 people with hypertension from primary care. We used a specific instrument, selfadministered, with 21 questions on factors that can hinder treatment, divided into four dimensions: medication, socioeconomic, institutional and personal beliefs. We adopted a significance level of $\mathrm{p}<0.05$. Results: The control of blood pressure was associated $(p<0.05)$ with female gender, Caucasian ethnicity, primary/secondary education, not drinking alcohol, higher income and regular physical activity. Regarding the factors that can hinder treatment, there was association of hypertension control with only two questions: "feel nothing" and "have to do treatment for life". Conclusion: Sociodemographic variables and beliefs concerning the absence of symptoms and chronicity of the disease influenced the control of hypertension and should be considered in the adherence process to the treatment.
\end{abstract}

\section{DESCRIPTORS}

Hypertension; Medication Adherence; Therapeutics; Life Style; Public Health Nursing. 


\section{INTRODUCTION}

Hypertension is a major risk factor for cardiovascular diseases, which cause significant impact on morbidity and mortality profiles. Thus, ischemic heart disease and stroke accounted for 12.9 million deaths worldwide in 2010, one in four deaths, which represented a significant increase when compared to the data of 1990, when one out of five resulted in deaths ${ }^{(1)}$.

Further to this scenario, the high prevalence rates of hypertension makes it a major public health problem. It is estimated that about $30 \%$ of the Brazilian adult population is hypertensive, and this rate doubles in elderly ${ }^{(2-3)}$.

Despite the proven efficacy of pharmacological and non-pharmacological measures in the treatment of hypertension, poor control of blood pressure is still very frequent. A review study evaluated that the control of hypertension in Brazilian in publications showed control rates below 50\% in most of them, except for two studies that showed rates of $52.4 \%$ and $57.6 \%{ }^{(4)}$.

We highlight that, in the context of chronic diseases, the control of blood pressure is directly related to adherence to treatment. There are several factors that can interfere in the adherence process: those related to the disease, such as chronicity and absence of symptoms to drug treatment, including treatment for life, adverse events and complex dosage schedules; and in non-drug treatment, the changes in habits and lifestyles. Regarding the characteristics of hypertensive patients, we emphasize the sociodemographic variables and health beliefs institutional aspects, the characteristics of the service and the relationship with the health team ${ }^{(5)}$.

Therefore, considering that several factors can contribute to low blood pressure control rates, they should be identified as early as possible to establish strategies that will benefit the hypertensive. Thus, the aim of this study was to identify the association between blood pressure control and the following variables: a) bio-social and lifestyle characteristics; and b) factors related to the antihypertensive treatment in hypertensive patients assisted in primary care.

\section{METHODS}

This is a cross-sectional, exploratory, descriptive, with quantitative approach field study, part of a Project for Public Policy, sponsored by the São Paulo Research FoundationFAPESP and approved by the Research Ethics Committee (N213/03). The sample was calculated considering a dichotomous variable in descriptive study, expecting a proportion of hypertension cases of $30 \%$, with precision of 0.10 ( 0.5 below and 0.5 above) to a $99 \%$ confidence level, as a result of 250 people investigated. Inclusion criteria were: adults ( $>18$ years); diagnosed with hypertension in medical records; belonging to the scope of community of the District; and follow-up for at least 6 months. Exclusion criteria: pregnant women with hypertension, because of the specificities of hypertension in pregnancy, and people with a history of drug abuse or mental disorders that could invalidate the Consent Form. The study was conducted in two Basic Health Units of the western region of the city of Sao Paulo, in the state of Sao Paulo, Brazil.
Data were collected by undergraduate and graduate nursing students duly empowered to do so. An interview was conducted with hypertensives using an instrument, which had already been previously tested in studies ${ }^{(5)}$, including variables that can influence blood pressure control. For identification of bio-social variables we evaluated: age, gender, ethnicity (self-declared color), marital status (with or without partner), education (illiterate, primary, secondary or Tertiary education) and income (in minimum salaries) ${ }^{1}$. The lifestyle characteristics analyzed were: physical activity (at least three times/week for 30 minutes), smoking (yes/no) and alcohol intake, identified by the Alcohol Use Disorders Identification Test (AUDIT) $)^{(6)}$.

The instrument used to evaluate the factors thought to be involved in the adherence process to the treatment had already been used in previous investigations ${ }^{(7-9)}$ and, in this study, their analysis have been improved. It consists of 21 questions preceded by a written guidance: "check the alternative that best matches the degree of influence that each subject could hinder treatment for hypertension”. The answer alternatives, in Likert Scale, had three levels: agree (3), undecided (2) and disagree (1). The questions of this instrument have been prepared considering the expertise of the researchers on the subject, as well as literature. The questions were grouped into four dimensions: medication, socioeconomic status, institutional aspects and personal beliefs. All questions are presented in Table 2. In the preparation of the instrument, it was submitted to an expert body of judges composed of five experts in the field of hypertension and adherence to treatment, all judges were empowered to analyze the instrument's purpose and concepts. We asked questions to be evaluated individually to determine whether they were appropriate for internal consistency, if it was related to the item to be evaluated and for clarity. As for the fair valuation, each question had similar value to others. The judges body was allowed to suggest modification or deletion of items considered irrelevant, inadequate or ambiguous, and when it occurred, they could provide more appropriate substitutions. After the analysis, the changes suggested by the judges were made, being accepted as equivalent items that had at least $80 \%$ agreement between raters. It adds further that this instrument was being improved in studies in which it was applied. It is noteworthy that during the present study, an educational process with hypertensives was developed about their health problems and treatment adherence, as well as nursing staff professionals. These activities were part of a Project for Public Policy developed in Basic Health Units at the time of data collection from this study, as previously mentioned. Thus, it is considered that hypertensive patients who presented influencing factors in the adherence process to the treatment received attention.

To assess adherence to drug treatment, we used the Morisky and Green's ${ }^{(7)}$ instrument, widely used and validated. This instrument consists of four questions that allow dichotomous answers (yes/no). We considered adherence to treatment when responses were negative to all of the following

1 The minimum national wage per month in Brazil corresponds to $\mathrm{R} \$ 880,00$ or U\$273,85 American dollars according to the Central Bank of Brazil on October 8th, 2016. 
questions: 1 - Do you often forget to take your medication? 2 - Are you inattentive from time to time to take your medicine? 3 - Do you stop taking the medicine if you feel better? 4 - Do you stop taking the medicine if you feel worse?

The measurement of blood pressure was conducted in Basic Health Units with a validated automatic device according to the VI Brazilian Guidelines on Hypertension ${ }^{(2)}$. To minimize the white coat phenomenon, blood pressure evaluation was performed by nursing undergraduate and graduate students, properly trained to do so, in a private room, after 5 minutes of rest, with three consecutive measurements with an interval of 2 minutes, and the average of the last two measurements was used to evaluate the blood pressure control. The measurements were performed with the participant in the sitting position, with the arm supported, and close to the third intercostal space, leaning back in the chair, feet on the floor and using the cuff according to the circumference of the arm. The blood pressure control was considered for values less than $140 \mathrm{mmHg}$ for systolic pressure and $90 \mathrm{mmHg}$ for diastolic pressure. Associations between control of blood pressure levels and the following variables were made: biosocial, lifestyle, Morisky and Green Test and factors that may hinder the treatment of hypertension, described above. For statistical analysis, we used the chi-square test and MannWhitney test, with a significance level of $\mathrm{p}<0.05$.

\section{RESULTS}

The study included 290 hypertensive patients with mean age in the sixth decade of life, most were female (62.1\%), Caucasian (54.5\%), income lower than three minimum salaries (59\%) and with primary and secondary education (71.9\%). From the total of hypertensive patients, $60 \%$ had controlled blood pressure.

Regarding bio-social and lifestyles characteristics of hypertensive patients, it was found that there was an association $(p<0.05)$ of blood pressure control with females, Caucasian, with primary and secondary education, who did not drink alcohol beverages. Having a lower income and lack of regular physical activity was associated with lack of control (Table 1).

Table 1 - Bio-social and lifestyle characteristics of hypertensives in association with the control of blood pressure - Sao Paulo, SP, Brazil, 2010.

\begin{tabular}{|c|c|c|}
\hline \multirow{3}{*}{ Variables } & \multicolumn{2}{|c|}{ Hypertensives } \\
\hline & Controlled & Uncontrolled \\
\hline & $\mathbf{n}$ & $\%$ \\
\hline
\end{tabular}

Age (years) $p=0.123$

$\begin{array}{lllll}\leq 60 & 85 & 48.9 & 46 & 39.7 \\ >60 & 89 & 51.1 & 70 & 60.3\end{array}$

Gender $p=0.048$

\begin{tabular}{lrrrr} 
Male & 58 & 33.3 & 52 & 44.8 \\
Female & 116 & 66.7 & 64 & 55.2 \\
\hline
\end{tabular}

...continuation

\begin{tabular}{|c|c|c|c|c|}
\hline \multirow{3}{*}{ Variables } & \multicolumn{4}{|c|}{ Hypertensives } \\
\hline & \multicolumn{2}{|c|}{ Controlled } & \multicolumn{2}{|c|}{ Uncontrolled } \\
\hline & $\mathrm{n}$ & $\%$ & $\mathbf{n}$ & $\%$ \\
\hline \multicolumn{5}{|l|}{ Ethnicity $p=0.020$} \\
\hline White & 104 & 62.3 & 54 & 48.2 \\
\hline Not white & 63 & 37.7 & 58 & 51.8 \\
\hline \multicolumn{5}{|l|}{ Marital status $p=0.945$} \\
\hline With partner & 106 & 61.3 & 70 & 60.9 \\
\hline Without partner & 67 & 38.7 & 45 & 39.1 \\
\hline \multicolumn{5}{|l|}{ Education $p=0.048$} \\
\hline Illiterate/Read and write & 33 & 47.1 & 37 & 52.9 \\
\hline Primary/secondary & 126 & 64.0 & 71 & 36.0 \\
\hline Tertiary education & 4 & 57.1 & 3 & 42.9 \\
\hline \multicolumn{5}{|l|}{ Ocuppation $p=0.514$} \\
\hline Housewife & 49 & 39.2 & 33 & 40.2 \\
\hline Unemployed & 3 & 2.4 & 5 & 6.1 \\
\hline Retired & 12 & 9.6 & 4 & 4.9 \\
\hline Self-employed & 53 & 42.4 & 34 & 41.5 \\
\hline Employment bond & 8 & 6.4 & 6 & 7.3 \\
\hline \multicolumn{5}{|c|}{ Family income (in minimum salary) $\mathbf{p}=\mathbf{0 . 0 3 4}$} \\
\hline$\leq 3$ & 96 & 60.8 & 75 & 73.5 \\
\hline$>3$ & 62 & 39.2 & 27 & 26.5 \\
\hline \multicolumn{5}{|c|}{ Physical activity practice $p=0.023$} \\
\hline No & 108 & 62.1 & 84 & 75.0 \\
\hline Yes & 66 & 37.9 & 28 & 25.0 \\
\hline \multicolumn{5}{|l|}{ Smoking $p=0.998$} \\
\hline No & 155 & 89.1 & 98 & 89.1 \\
\hline Yes & 19 & 10.9 & 12 & 10.9 \\
\hline \multicolumn{5}{|l|}{ Alcohol intake $p=0.013$} \\
\hline No & 112 & 70.4 & 54 & 54.5 \\
\hline $\begin{array}{l}\text { Drink or stopped drinking } \\
\text { for at least a year }\end{array}$ & 47 & 28.6 & 45 & 45.4 \\
\hline
\end{tabular}

There was a statistically significant association $(p<0.05)$ between the control of blood pressure and the degree of agreement with the different factors that can influence the treatment for high blood pressure in just two questions affecting the domain personal beliefs. From the total of hypertensives that indicated the alternative "agree" with the fact that "I feel nothing", 63.7\% were controlled against and $36.3 \%$ uncontrolled, and that $85.7 \%$ of those who pointed out the alternative "undecided" were also not controlled. As for "having treatment for life", 66.1\% were in agreement and were controlled hypertensive versus $33.9 \%$ uncontrolled and only two were undecided and uncontrolled (Table 2). 
Table 2 - Controlled and uncontrolled hypertension according to the responses to the investigation form of hindering factors of treatment - Sao Paulo, SP, Brazil, 2010.

\begin{tabular}{|c|c|c|c|c|c|c|}
\hline \multirow{3}{*}{ Factor that can hinder treatment } & \multicolumn{6}{|c|}{ HYPERTENSIVES } \\
\hline & \multicolumn{3}{|c|}{ Controlled } & \multicolumn{3}{|c|}{ Uncontrolled } \\
\hline & $\begin{array}{l}\text { Agree (1) } \\
n \%\end{array}$ & $\begin{array}{l}\text { Undecided (2) } \\
\text { n \% }\end{array}$ & $\begin{array}{c}\text { Disagree (3) } \\
\mathbf{n} \%\end{array}$ & $\begin{array}{l}\text { Agree (1) } \\
\text { n \% }\end{array}$ & $\begin{array}{l}\text { Undecided (2) } \\
\text { n \% }\end{array}$ & $\begin{array}{l}\text { Disagree (3) } \\
\mathrm{n} \%\end{array}$ \\
\hline \multicolumn{7}{|c|}{ MEDICINES } \\
\hline $\begin{array}{l}\text { - The drugs cause adverse events } \\
p=0.965\end{array}$ & 5558.5 & 550.0 & 9559.7 & 3941.5 & 550.0 & 6440.3 \\
\hline $\begin{array}{l}-I \text { forget to take my medicine } \\
p=0.772\end{array}$ & 9660.4 & 150.0 & 5956.2 & 6339.6 & 150.0 & 4643.8 \\
\hline $\begin{array}{l}- \text { I need help to take medicine } \\
p=0.775\end{array}$ & 3557.4 & 375.0 & 11658.3 & 2642.6 & 125.0 & 8341.7 \\
\hline $\begin{array}{l}-I \text { have too many medicines to } \\
\text { take } p=0.224\end{array}$ & 6462.7 & 583.3 & 8555.6 & 3837.3 & 116.7 & 6844.4 \\
\hline $\begin{array}{l}-I \text { do not know how to take the } \\
\text { medicines } \\
p=0.283\end{array}$ & 6664.1 & 375.0 & 8655.1 & 3735.9 & 125.0 & 7044.9 \\
\hline $\begin{array}{l}\text { - Treatment is complicated, hard } \\
\mathrm{p}=0.842\end{array}$ & 4858.5 & 675.0 & 10359.5 & 3441.5 & 225.0 & 7040.5 \\
\hline \multicolumn{7}{|c|}{ SOCIOECONOMIC } \\
\hline $\begin{array}{l}- \text { I have no money to buy } \\
\text { medicines } p=0.645\end{array}$ & 7160.2 & 1100.0 & 8457.5 & 4739.8 & 00.0 & 6242.5 \\
\hline $\begin{array}{l}\text { - I have no one to watch my } \\
\text { children/grandchildren } \\
p=0.462\end{array}$ & 4862.3 & 250.0 & 10657.3 & 37.7 & 50.0 & 42.7 \\
\hline $\begin{array}{l}\text { - I need company to go to } \\
\text { consultations } \\
p=0.535\end{array}$ & 3154.4 & 2100.0 & 12459.6 & 2645.6 & 00.0 & 8440.4 \\
\hline $\begin{array}{l}\text { I miss work to go to } \\
\text { consultations } \\
p=0.706\end{array}$ & 4554.2 & 228.6 & 10561.8 & 3845.8 & 571.4 & 6538.2 \\
\hline $\begin{array}{l}\text { - Distance to consultation site } \\
p=0.934\end{array}$ & 4758.8 & 150.0 & 10659.2 & 3341.3 & 150.0 & 7340.8 \\
\hline $\begin{array}{l}\text { - Lack money for transportation } \\
p=0.140\end{array}$ & 2955.8 & 133.3 & 12459.6 & 2344.2 & 266.7 & 8440.4 \\
\hline \multicolumn{7}{|c|}{ INSTITUTIONAL } \\
\hline $\begin{array}{l}- \text { The waiting time is too long } \\
p=0.965\end{array}$ & 8858.3 & 266.7 & 6559.1 & 6341.7 & 133.3 & 4540.9 \\
\hline $\begin{array}{l}\text { - I did not get along with the staff } \\
\text { team } \\
p=0.596\end{array}$ & 6460.4 & 450.0 & 9058.8 & 4239.6 & 450.0 & 6341.2 \\
\hline $\begin{array}{l}- \text { The service time is inconvenient } \\
\mathrm{p}=0.239\end{array}$ & 5254.2 & 150.0 & 10461.9 & 4445.8 & 150.0 & 6438.1 \\
\hline $\begin{array}{l}\text { - Lack of physician for } \\
\text { consultation } \\
p=0.362\end{array}$ & 11757.9 & 00.0 & 4262.7 & 8542.1 & 1100.0 & 2537.3 \\
\hline \multicolumn{7}{|c|}{ PERSONAL BELIEFS } \\
\hline $\begin{array}{l}- \text { I do not feel anything } \\
\mathbf{p}=\mathbf{0 . 0 2 9}\end{array}$ & 7263.7 & 114.3 & 8358.5 & 4136.3 & 685.7 & 5941.5 \\
\hline $\begin{array}{l}- \text { Being treated for life } \\
\mathbf{p}=\mathbf{0 . 0 1 3}\end{array}$ & 8266.1 & 2100.0 & 7150.7 & 4233.9 & 00.0 & 6949.3 \\
\hline $\begin{array}{l}-I \text { do not feel the need to get } \\
\text { treatment } \\
p=0.734\end{array}$ & 4758.0 & 545.5 & 10659.9 & 3442.0 & 654.5 & 7140.1 \\
\hline $\begin{array}{l}-I \text { do not feel I am getting better } \\
p=0.638\end{array}$ & 7762.0 & 450.0 & 7757.0 & 4638.0 & 450.0 & 5843.0 \\
\hline $\begin{array}{l}\text { - I only take medicines when I } \\
\text { feel bad } \\
p=0.630\end{array}$ & 5656.6 & 466.7 & 9459.1 & 4343.4 & 233.3 & 6540.9 \\
\hline
\end{tabular}


Analyzing the total of hypertensive responses that indicated the alternative "agree" with the hinder factor for treatment, appointed in each issue, we highlight the following aspects. In the context of medical treatment, "forgetting" had the highest percentage of agreement (59.8\%) and just over a third agreed to "adverse events" (35.7\%), "too many medications" (39.1\%) "I do not know how to take them" (39.5\%) and "complicated treatment" (31.2\%). In the socioeconomic dimension, there was greater agreement for "not having money to buy the medicines" (44.5\%), followed by "miss work to go to consultation" (31.9\%) and "distance to consultation site" (30.6\%). In the institutional aspects, the largest agreements were for "lack of physician" (74.8\%) and "long wait" (57.2\%), followed by "not getting along with the staff" (39.7\%) and "inconvenient time of service" (36.1\%). In the personal belief dimension, agreement was around $40 \%$ for "asymptomatic disease" (43.1\%), "treatment for life" (46.1\%) and "I do not feel better" (46.4\%); and little less indicated "I do not feel the need to get treatment" (30.1\%) and "only take medicine when I feel bad" (37.5\%).

The data in Table 3 show that there was no statistically significant difference in the mean (standard deviation) of the degree of agreement between the controlled and uncontrolled hypertension, with the factors that can hinder treatment when assembled in the four dimensions evaluated.

Table 3 - Controlled and uncontrolled hypertensives according to the mean agreement of the four dimensions of the investigation form of hindering factors for treatment - São Paulo, SP, Brazil, 2010.

\begin{tabular}{|c|c|c|c|c|}
\hline \multicolumn{5}{|c|}{ Hypertensives } \\
\hline & \multirow{2}{*}{\multicolumn{2}{|c|}{$\begin{array}{c}\text { Controlled } \\
\begin{array}{c}\text { Mean (standard } \\
\text { deviation) }\end{array}\end{array}$}} & \multirow{2}{*}{\multicolumn{2}{|c|}{$\begin{array}{l}\text { Uncontrolled } \\
\begin{array}{c}\text { Mean (standard } \\
\text { deviation) }\end{array}\end{array}$}} \\
\hline & & & & \\
\hline \multicolumn{5}{|c|}{ DIMENSIONS } \\
\hline $\begin{array}{l}\text { Medication } \\
p=0.729\end{array}$ & 15.54 & $(4.97)$ & 15.36 & (5.34) \\
\hline $\begin{array}{l}\text { Socioeconomic } \\
p=0.975\end{array}$ & 8.88 & $(3.57)$ & 9.03 & (3.70) \\
\hline $\begin{array}{l}\text { Institutional } \\
p=0.677\end{array}$ & 11.125 & $(3.81)$ & 11.36 & (3.63) \\
\hline $\begin{array}{l}\text { Personal beliefs } \\
p=0.219\end{array}$ & 7.43 & $(2.7)$ & 7.009 & (2.53) \\
\hline
\end{tabular}

It was also observed that there was no statistically significant association between blood pressure control and the Morisky and Green Test, which evaluated the adherence to drug treatment (Table 4).

Table 4 - Controlled and uncontrolled hypertensive according to Morisky and Green test - Sao Paulo, SP, Brazil, 2010.

\begin{tabular}{lccccccc}
\hline Variables & \multicolumn{4}{c}{ Hypertensives } & \multicolumn{2}{r}{ P value } \\
\hline Morisky and & \multicolumn{1}{c}{ Controlled } & Uncontrolled & \multicolumn{2}{c}{ Total } & \\
\cline { 2 - 7 } Green Test & $\mathbf{n}$ & $\%$ & $\mathbf{n}$ & $\%$ & $\mathbf{n}$ & $\%$ & 0.715 \\
Non adhrence & 118 & 60.8 & 76 & 39.2 & 194 & 100 & \\
Adherence & 60 & 62.5 & 36 & 37.5 & 96 & 100 & \\
\hline
\end{tabular}

\section{DISCUSSION}

The main findings of this study showed that the chronicity of the disease and the absence of symptoms of hypertension were factors reported by hypertensive patients that can hinder disease control, beyond the tension control of the association with bio-social characteristics and lifestyles of hypertensive people. Therefore, the personal beliefs of hypertensive patients on the disease and treatment deserve attention in the thematic treatment adherence. Hypertension is a disease with no specific symptoms, in most cases, and only blood pressure values can determine the diagnosis. Therefore, the lack of symptoms may further influence the degree of importance or not that hypertensive people indicate the disease and the need for treatment. Additionally, the need for treatment for life, which includes, in addition to drug therapy, changes in habits and lifestyles. A study with coronary patients, all of them hypertensive patients, showed that the majority did not consider the chronic nature of the disease, believing that the treatment would not last a lifetime and that they would cure the disease ${ }^{(10)}$. Moreover, also concerning the beliefs of hypertensive patients, it was found that just over one third indicated they "did not feel the need to get treatment" and "only take medicine when I feel bad" conditions that can also be barriers to satisfactory adherence to treatment and subsequent control of hypertension.

Adherence to treatment can be defined by the degree of match between a person's behavior, such as taking medication, following a diet, changing habits and lifestyles, and the therapeutic proposal. The main reason for inadequate control of high blood pressure seems to be the failure of long-term treatment in both lifestyle modifications as with regard to drug therapy. Adherence problems are not always easy to detect, even more difficult is its quantification, and control of blood pressure is an objective fact which may indicate favorable performance of adherence. Attempts of an objective assessment of adherence to drug treatment is verified in the literature, and Morisky and Green Test is a frequently used instrument. The characteristics of this instrument are directed to the identification and assessment of problems and barriers of adherence. It can be used as a diagnostic tool to evaluate the degree of adherence with the proposed therapy by patients and their adherence behaviors. It also highlighted that the Morisky and Green test can identify problems related to attitudes and behavior and then target for strategies to solve the elements that may hinder adherence to treatment and consequently the control of hypertension. Perhaps, this is the great advantage of the test, as in the present study there was no association between blood pressure control and adherence to treatment by the test, only $33 \%$ of hypertensive patients presented adherence, while $60 \%$ had their blood pressure controlled values.

Noteworthy, treatment adherence in chronic diseases such as hypertension, implies behavioral changes and this is not an easy task. Subsidizing patients with information about their health problems is the first step for the health education process, but the desired changes are not enough for them to occur. Thus, the behavior is determined not only 
by the cognitive aspects, but mainly emotional aspects, as beliefs, values, and perceived barriers regarding the behavior to be adopted. When the behavior in question is the adherence to certain treatment, each person makes use not only of knowledge about the disease, but also is guided by a range of reasons for adopting or not such behavior. The individual rationalizes the problem, the possible alternatives, the positive or negative aspects and tries to adjust their attitudes to what suits them best according to their beliefs ${ }^{(11)}$.

It is considered that the lack of hypertension control association with the vast majority of questions in Table 2 should not be considered in the evaluation of hypertensive patients. There was significant degree of agreement as a complicating factor for treatment with important issues in drug area, such as forgetting to take medication and complex schedules, results found in other studies ${ }^{(12-13)}$. Accordingly, the fixed drug combination is a strategy that increases the adherence ${ }^{(14)}$. In the socio-economic dimension, the lack of money to buy medicines strengthens the control of the association found blood pressure levels with lower income. But in primary care, the HIPERDIA program - Registration System and Monitoring of Hypertensive and Diabetics ${ }^{(15)}$, which provides delivery of medications, is emphasized. In the institutional aspects, the lack of physicians is a worrying statistic, which unfortunately is still present on the national scenario. The relationship with the health team is paramount to establish favorable conditions for the involvement of the patient with their health problems; the contract of establishment in which are explicit rights and duties of both the patient and the professional can be a good strategy to do so. A study ${ }^{(16)}$ which analyzed the efficiency of the care of the Family Health Strategy from beliefs of professionals showed that $53.4 \%$ rated the service negatively, emphasizing the need to modify or eliminate barriers in order to improve the conditions of service for its users.

More than half (60\%) of the studied hypertensive patients had controlled blood pressure, slightly higher rates when compared to other national studies ${ }^{(4,17-19)}$. Among the bio-social characteristics of hypertensive patients that were associated with the control, the fact that women are more controlled also coincides with the results of other studies $^{(20-22)}$. This finding may be a matter of gender, women seem to present a better understanding of their health and therefore, seek health services more often and follow treatments. The lack of control in non-white hypertensive patients with lower income and lower education, refers to the association between these variables and hypertension. National data have shown a higher prevalence of hypertension in blacks and low-income populations. Mortality rates per 100,000 inhabitants in Brazil, in 2010, adjusted for age, for high blood pressure in white, brown and black men/women were, respectively, 11.9/17.0, 16.3/22.0, and $28.8 / 34.5^{(23)}$. In this sense, a study in 17 countries evaluated the cardiovascular risk according to income, and the results showed that the number of cardiovascular events per thousand was lower $(\mathrm{p}<0.001)$ in those with higher incomes (3.99) compared to the mean (5.38) in low income families
$(6.43)^{(24)}$. These data are compelling in demonstrating the significant association between socioeconomic background and cardiovascular risk factors, such as hypertension.

Therefore, inadequate habits and lifestyles predispose or may be associated with a higher prevalence of hypertension and risk factors for elevated blood pressure, such as alcohol intake and lack of regular physical activity. The association between alcohol and hypertension is well proven ${ }^{(25)}$, as well as its influence on disease control. As for physical activity, the reduction of blood pressure after exercise, especially in hypertensive patients, is also well documented ${ }^{(26)}$.

Populational, descriptive and exploratory studies are important, but investigations of this nature do not allow researchers to establish cause and effect relationships. The propositions of intervention studies, such as randomized controlled trials, are essential to evaluate interventions that benefit adherence to antihypertensive treatment. Another limiting factor of this study would be that the sample size, which belonged to a specific context of primary care in the city of Sao Paulo. The two health units where the data were collected belong to a university center, and therefore, results may occur differently in other contexts.

\section{CONCLUSION}

The main conclusion of this study was that only two questions - of the various factors evaluated identified as influencers in the adherence process to antihypertensive treatment - were associated with blood pressure control. Therefore, the absence of symptoms and chronicity of hypertension, closely related to personal beliefs about the disease and its treatment were relevant aspects pointed out by the studied hypertensive patients. However, it is emphasized, once more, that treatment adherence, which helps controlling the disease, preventing and minimizing damage to target organs, is a complex process. The combination of pressure control with variables such as gender, social conditions and unfavorable lifestyles exemplifies the large magnitude of the problem.

The work of nurses in the context of care for hypertensives should include all stages of care, starting out by primary prevention, through strategies focusing on the changes and the adoption of habits and healthy lifestyles. The periodic measurement of blood pressure should be part of all health assessments, it is the only way to identify changes in blood pressure levels. In the treatment, the great challenge is to control the disease, directly related to the adherence process. Thus, nurses should provide tools to meet the real needs of hypertensive patients and the nursing consultation is an instrument of action that can be useful in these circumstances. During the nursing consultation, intervening factors can be identified in the adherence process to antihypertensive treatment, related to biopsychosocial variables of the hypertensive person, such as age, gender, socioeconomic status and psycho-emotional aspects; to drug and non-drug treatment; the beliefs and knowledge about the disease and treatment; and the habits and lifestyles. Thus, the instrument presented in this study can be useful. 


\section{RESUMO}

Objetivo: Identificar a associação entre o controle da pressão arterial e as seguintes variáveis: a) características biossociais e hábitos de vida dos hipertensos; e b) fatores relacionados ao tratamento anti-hipertensivo. Métodos: Realizou-se estudo exploratório com 290 hipertensos da atenção primária. Utilizou-se de instrumento específico, autoaplicável, com 21 questões sobre fatores que podem dificultar o tratamento, divididas em quatro domínios: medicamentos, socioeconômico, institucional e crenças pessoais. Adotou-se nível de significância de $\mathrm{p}<0,05$. Resultados: $\mathrm{O}$ controle da pressão arterial se associou $(\mathrm{p}<0,05)$ com sexo feminino, etnia branca, ensino fundamental/médio, não ingerir bebida alcoólica, maior renda e atividade física regular. Quanto aos fatores que podem dificultar o tratamento, houve associação do controle com apenas duas questões: "não sentir nada" e "ter que fazer tratamento para vida toda". Conclusão: Variáveis sociodemográficas e crenças relativas à ausência de sintomatologia e cronicidade da doença influenciaram o controle dos hipertensos e devem ser consideradas no processo de adesão ao tratamento.

\section{DESCRITORES}

Hipertensão; Adesão à Medicação; Terapêutica; Estilo de Vida; Enfermagem em Saúde Pública.

\section{RESUMEN}

Objetivo: Identificar la asociación entre el control de la presión arterial y las siguientes variables: a) características biosociales y hábitos de vida de los hipertensos; y b) factores relacionados con el tratamiento antihipertensivo. Métodos: Se llevó a cabo estudio exploratorio con 290 hipertensos de la atención primaria. Se utilizó un instrumento específico, autoaplicable, con 21 cuestiones sobre factores que pueden dificultar el tratamiento, divididas en cuatro dominios: fármacos, socioeconómico, institucional y creencias personales. Se adoptó nivel de confianza de $\mathrm{p}<0,05$. Resultados: El control de la presión arterial se asoció $(\mathrm{p}<0,05)$ con sexo femenino, etnia blanca, educacional básica/media, no ingerir bebida alcohólica, mayores ingresos y actividad física regular. En cuanto a los factores que pueden dificultar el tratamiento, hubo asociación del control con solo dos cuestiones: "no sentir nada" y "tener que hacer tratamiento para toda la vida”. Conclusión: Variables sociodemográficas y creencias relativas a la ausencia de sintomatología y cronicidad de la enfermedad influenciaron el control de los hipertensos y deben considerarse en el proceso de adhesión al tratamiento.

\section{DESCRIPTORES}

Hipertensión; Complimiento de la Medicación; Terapéutica; Estilo de Vida; Enfermería en Salud Pública.

\section{REFERENCES}

1. Lozano R, Naghavi M, Foreman K, Lim S, Shibuya K, Aboyans V, et al. Global and regional mortality from 235 causes of death for 20 age groups in 1990 and 2010: a systematic analysis for the Global Burden of Disease Study 2010. Lancet. 2012;380(9859):2095-128.

2. Picon RV, Fuchs FD, Moreira LB, Riegel G, Fuchs SC. Trends in prevalence of hypertension in Brazil: a systematic review with meta-analysis. PLoS One. 2012;7(10):e48255.

3. Villela PB, Klein CH, Oliveira GMM. Trends in Mortality from Cerebrovascular and Hypertensive Diseases in Brazil Between 1980 and 2012. Arq Bras Cardiol. 2016; 107(1):26-32.

4. Pinho NA, Pierin AMG. Hypertension Control in Brazilian Publications. Arq Bras Cardiol. 2013;101(3):65-73.

5. Lo SHS BN, Chau JPC, Woo J, Thompson DR, Choi KC. Adherence to Antihypertensive Medication in Older Adults With Hypertension. J Cardiovasc Nurs. 2016;31(4):296-303.

6. World Health Organization (WHO). Problems related to alcohol consumption Report of a WHO Expert Committee. Genebra: WHO; 1980. (Report Series, 650).

7. Pérez-Escamilla B, Franco-Trigo L, Moullin JC, Martínez-Martínez F, García-Corpas Identification of validated questionnaires to measure adherence to pharmacological antihypertensive treatments. Patient Prefer Adherence. 2015;9:569-78.

8. Marques PAC, Pierin AMG. Factors that affect cancer patient compliance to oral anti-neoplastic therapy. Acta Paul Enferm. 2008;21(2):323-32.

9. Silva SBE, Colósimo FC, Pierin AMG. The effect of educational interventions on nursing team knowledge about arterial hypertension. Rev Esc Enferm USP 2010;44(2):482-9.

10. Gama GGG, Mussi FC, Pires CGS, Guimarães AC. Crenças e comportamentos de pessoas com doença arterial coronária. Ciênc Saúde Coletiva. 2012;17(12):3371-83

11. Ajzen I, Fishbein M. Predicting and changing behavior: the reasoned action approached. New York: Taylor and Francis Group; 2010.

12. Nwabuo CC, Dy SM, Weeks K, Young JH. Factors associated with appointment non-adherence among african-americans with severe, poorly controlled hypertension. PLoS One. 2014;9(8):e103090.

13. Magnabosco P, Teraoka EC, Oliveira EM, Felipe EA, Dayana Freitas D, Marchi-Alves LM. Comparative analysis of non-adherence to medication treatment for systemic arterial hypertension in urban and rural populations. Rev Latino Am Enfermagem. 2015;23(1):20-7.

14. Thom S, Poulter N, Field J, Patel A, Prabhakaran D, Stanton A, et al. Effects of a fixed-dose combination strategy on adherence and risk factors in patients with or at high risk of CVD the UMPIRE randomized clinical trial. JAMA. 2013;310(9):19-29.

15. Brasil. Ministério da Saúde. Portaria Conjunta n. 112, de 19 de junho de 2002. Institui o fluxo de alimentação da base nacional do Hiperdia [Internet]. Brasília; 2002 [citado 2015 dez. 15]. Disponível em: http://www.cosemsmg.org.br/sishiperdia/index.shtml.

16. Albuquerque FJB, Melo CF, Souza Filho FE, Araújo Neto JL. Avaliação da estratégia saúde da família a partir das crenças dos profissionais. Estud Psicol (Campinas). 2011; 28(3):363-70.

17. Bastos MM, Kluthcovsky ACGC, Schafranski MD. Controle da pressão arterial em idosas hipertensas em uma Unidade de Saúde da Família e fatores associados. Cad Saúde Coletiva. 2016;24(1):111-7. 
18. Sorlie PD, Allison MA, Avilés-Santa ML, Cai J, Daviglus ML, Howard AG, et al. Prevalence of hypertension, awareness, treatment, and control in the Hispanic Community Health Study/Study of Latinos. Am J Hypertens. 2014;27(6):793-800.

19. Egan BM, Li J, Small J, Nietert PJ, Sinopoli A.The growing gap in hypertension control between insured and uninsured adults: National Health and Nutrition Examination Survey 1988 to 2010. Hypertension. 2014;64(5):997-1004.

20. Candy D, Kang CD, Prilla PM, Tsanga I, Winson TL, Harry HX, et al. Determinants of medication adherence and blood pressure control among hypertensive patients in Hong Kong: a cross-sectional study. Int J Cardiol. 2015;182:250-7.

21. Souza CS, Stein AT, Bastos GA, Pellanda LC. Blood pressure control in hypertensive patients in the "Hiperdia Program": a territory-based study. Arq Bras Cardiol. 2014;102(6):571-78.

22. Yongqing Z, Ming W, Jian S, Pengfei L, Xiaoqun P, Meihua D, et al. Prevalence, awareness, treatment and control of hypertension and sodium intake in Jiangsu Province, China: a baseline study in 2014. BMC Public Health. 2015;16:56.

23. Lotufo PA, Bensenor IJM. Raça e mortalidade cerebrovascular no Brasil. Rev Saúde Publica. 2013;47(6):1201-4.

24. Yusuf S, Rangarajan SK, Téo I, Islam S, Li W, Liu L, et al. Cardiovascular risk and events in 17 low, middle and high-income countries. N Engl J Med. 2014;371(9):818-27.

25. Husain K, Ansari RA, Ferder L. Alcohol-induced hypertension: mechanism and prevention. World J Cardiol. 2014;26;6(5):245-52.

26. Semlitsch T, Jeitler K, Hemkens LG, Horvath K, Nagele E, Schuermann C, et al. Increasing physical activity for the treatment of hypertension: a systematic review and meta-analysis. Sports Med. 2013;43(10):1009-23. 